\title{
Spin-off as an indicator of regional innovation network development
}

Konstantin I Grasmik ${ }^{1,2}$

Correspondence: simpfor@rambler.ru 'Dostoevsky F.M Omsk State University, 55a, Prospect Mira, Omsk 644077, Russia

${ }^{2}$ Center of Entrepreneurship and Innovation, Skolkovo Institute of Science and Technology, 100

Novaya str., Moscow 143025, Russia

\begin{abstract}
It is not easy to design an appropriate indicator of network collaboration that is relevant and comparable to all regions of the Russian Federation. This is a challenge because the creation of high-tech start-ups requires the cooperation of various and heterogeneous stakeholders: inventor, entrepreneur, investor, and the university. Accordingly, the purpose of this paper is to test the following hypothesis: the greater the number of viable spin-offs in the region, the higher the level of innovative activity of the region. The object of analysis is Russian spin-offs, which were created during the period from August 2009 to May 2014. Using their founders' profiles, I obtained the university affiliation of these companies. I also gathered information about their industry affiliation, size, turnover, regional (country) identity, etc. Using this data, I developed a number of indicators characterizing the intensity of interaction between universities and companies. I show that there is a positive link between innovation activity and performance indicators describing the intensity of interaction between universities and companies at the regional level.

In closing, I offer a few comments about the possibility of using the results of this research in the analysis of applied problems related to innovation policy and the development of ratings for the innovative activity of regions.
\end{abstract}

JEL classification: $0170 ; 0310 ; 0320$

Keywords: Spin-off; Entrepreneurial university; Innovation network; Regional innovation system

\section{Springer}

(C) 2015 Grasmik. This is an Open Access article distributed under the terms of the Creative Commons Attribution License (http:// creativecommons.org/licenses/by/4.0), which permits unrestricted use, distribution, and reproduction in any medium, provided the original work is properly credited. 
Spanish: Empresas spin-off como indicadores del desarrollo de las redes de innovación regional.

Resumen: No es fácil diseñar un indicador que refleje adecuadamente la colaboración en las redes de innovación que sea relevante y comparable a lo largo de todas las regiones de la Federación Rusa. Este es un reto porque la creación de empresas incipientes (start-ups) de tecnología de punta requiere la colaboración de varios y heterogéneos participantes: inventor, empresario, inversor, y la universidad. El objetivo de este artículo es examinar la siguiente hipótesis: cuanto más alto sea el número de empresas spin-off en la región, tanto más alto será el nivel de actividad innovadora de la región.

Este análisis se enfoca empíricamente en empresas spin-off creadas entre agosto del 2009 a mayo del 2014 en Rusia. Usando el perfil de sus fundadores, pude establecer la afiliación de estas empresas con universidades. También obtuve información sobre el sector industrial al que pertenecen, su tamaño, facturación, e identidad regional o nacional, y otros datos más. A partir de esta información, desarrollé un conjunto de indicadores sobre la intensidad de la interacción entre universidades y empresas. Usando toda esta información, muestro que a nivel regional existe una relación positiva entre actividad innovadora y la intensidad de la interacción entre universidades y empresas.

Concluyo comentando dos posibles usos de esta investigación. Primero, puede iluminar problemas relacionados a políticas de la innovación. Segundo, puede ser útil en el desarrollo de un sistema de calificación de la actividad innovadora regional en Rusia.

French: Les Spin-offs comme indicateur de développement du réseau d'innovation régional

Résumé: II n'est pas facile de définir un indicateur approprié pertinent et comparable pour toutes les régions de la Fédération Russe. La création de start-ups de haute technologie exige la coopération de tous : les inventeurs, les investisseurs et l'université en tant qu'organisation dont les ressources sont utilisées pour le développement de l'innovation. En conséquence, le but de cet article est de vérifier l'hypothèse suivante: plus le nombre de spin-offs dans une région est élevé, plus le niveau d'activités d'innovation de la région est élevé.

L'objet de cette analyse est les spin-offs Russes créés entre août 2009 et mai 2014. L'analyse des profils de leurs fondateurs m'a permis de déterminer leur affiliation à une université: j'ai aussi rassemblé des données sur le secteur industriel auquel elles appartiennent, leur taille, leur chiffre d'affaire, leur région (pays), leur identité, etc. J'ai ensuite développé un ensemble d'indicateurs pour caractériser l'intensité de l'interaction entre les universités et les entreprises au niveau régional. En conclusion, j'ai montré les applications possibles de ces résultats à l'analyse des problèmes liés aux politiques d'innovation et au développement d'une classification de l'activité innovatrice régionale. 
Russian: Спин-офф как индикатор развития региональной инновационной сети

Анотация: Известно, что инновационные сети оказывают влияние на функционирование инновационной системы и ее эффективность. В то же время, актуальной задачей является разработка системы индикаторов, которая сможет применяться и будет сопоставима в различных регионах, отражая сетевые взаимодействия. Создание высокотехнологичных старт-апов предполагает кооперацию всех заинтересованных лиц: изобретателя, предпринимателя, инвестора и университета как организации, чьи ресурсы используются в развитии инновационных идей. Следовательно, целью настоящего исследования является проверка следующей гипотезы: чем больше число жизнеспособных спин-офф компаний в регионе, тем выше уровень инновационной активности у местных компаний.

Объектом исследования являются российские спин-офф компании, созданные в период с августа 2009 года по май 2014 года. Анализ учредителей этих компаний позволил выделить и охарактеризовать юридические лица, связанные с университетами посредством спин-офф, по следующим показателям: принадлежность к отрасли промышленности, размер, объем продаж, территориальная идентичность (регион, страна) и т.д. На основании этих данных автором разработан ряд индикаторов, отражающих интенсивность взаимодействия между университетами и компаниями. Отмечена положительная взаимосвязь между инновационной активностью и значениями показателей, что характеризует интенсивность взаимодействия между университетами и компаниями на региональном уровне. В заключение, были сделаны выводы о возможности использования результатов данного исследования в анализе прикладных проблем, относящихся к инновационной политике и разработке рейтингов инновационной активности регионов.

Chinese: 作为区域创新网络开发指标的衍生公司

摘 要: 众所周知,创新网络会影响创新体系的运作和效果区但有个问题:如何设计对 于所有地区都具有相关性和可比性并反映网络合作的一个合适的指标。高科技 初创企业的创建需要所有利益相关方的合作，包括发明人、创业者对资人和利用 资源发展创新理念的组织一一大学。因此, 这项研究的目的在于考查下列假设:在 某一区域中能存活的衍生公司数目越多,当地公司的创新活动水平就越高。 本文的分析对象是在俄罗斯自2009年8月至2014年5月所创建的衍生公司。对衍 生公司创建者的分析揭示了通过一个衍生公司与大学关联起来的企业的特征,包 括它们的行业隶属关系区规模区营业额、地区(国家)的身份，等等。接下来我开发 了一些指标,表征大学和企业之间的互动强度。结果表明:在区域层次上,创新活动 水平和描述大学-公司相互作用强度的绩效指标是正相关的。 总之,本文提出了几点意见,探索利用这项研究成果分析与创新政策和评级区域创 新活动水平相关的实际问题的可能性。 
Portuguese: Spin-off como um indicador de desenvolvimento da rede de inovação regional

Resumo: Sabe-se que as redes de inovação têm um impacto sobre o funcionamento do sistema de inovação e sua eficácia. Mas existe um problema na concepção de um indicador apropriado, que possa ser relevante e comparável em todas as regiões e reflita as redes de colaboração. A criação de startups de alta tecnologia requer a cooperação de todas as partes interessadas: o inventor, o empreendedor, o investidor e a universidade como uma organização cujos recursos são utilizados no desenvolvimento de idéias inovadoras. Portanto, a proposta dessa pesquisa é verificar a seguinte hipótese: quanto maior o número de spin-offs viáveis na região, maior o nível de atividade inovadora das empresas locais.

O objeto de análise são spin-offs Russas, as quais foram criadas no período entre agosto de 2009 e maio de 2014. A análise dos fundadores das empresas permitiu caracterizá-las como spin-offs devido à relação com a universidade além de avaliar: o setor econômico a que pertencem, o tamanho, o volume de negócios, a identidade regional (país), etc. Em seguida, foi desenvolvido uma série de indicadores que caracterizam a intensidade da interação entre universidades e empresas. Verifica-se que existe uma relação positiva entre a atividade de inovação e os indicadores de desempenho que descrevem a intensidade de interação entre as universidades e as empresas a nível regional.

Na conclusão, eu faço alguns comentários sobre a possibilidade de se utilizar os resultados desta pesquisa para a análise de problemas aplicados relativos à política de inovação e o desenvolvimento de classificações para a atividade inovadora das regiões.

\section{Multilingual abstract}

Please see Additional file 1 for translation of the abstract into Arabic.

\section{Introduction}

The essence of innovation, nature, and models of the innovation process, its participants and incentive mechanisms are well characterized in economic science. It is known that proximity (first of all social, geographical, institutional) of participants of the innovation process favors knowledge exchange, stimulates appearance, and strengthens links among participants of the innovation process (innovation network) and as a result contributes significantly to the increase of innovative activity (Cassi and Plunket 2013; Balland 2012; Boschma and Broekel 2012; Boschma 2005). Indeed, networking helps, firstly, form trust between economic agents, which is essential to accelerate the exchange of implicit knowledge, secondly, increases flexibility and intensity of cooperation, thirdly, intensifies collective learning, etc. Entrepreneurs, engaged in commercialization of radical innovations, are more inclined to use innovation networks as a tool for access to critical resources and as a way of impact on the external agents (Ramachandran and Ramnarayan 1993).

In developing countries, interpersonal cooperation between scientists of universities (scientific organizations) and small and medium enterprises is much more intense than formal collaboration. In the context of an unfriendly business environment, administrative pressure, high cost of resources, and weak innovation infrastructure in almost all universities cooperation with an external company can be a decisive factor of start-up development (Degroof and Roberts 2003). Indeed, the amount 
of capital required to implement high-tech project, often exceeds many times the size of state grants to support entrepreneurship. But the most important directions of cooperation components are marketing and manufacturing components. For example, there are analysis of the needs of potential customers, promotion of access to customers, development of samples, and fine-tuning of technologies, development of market forecasts, etc., i.e., something that often cannot be purchased for money (Abbate and Cesaroni 2014; Erden and Yurtseven 2012).

Spin-off is the institution which has a number of advantages for the study of the productivity of the interaction of universities with companies. Firstly, in market economy, spin-off is a common form of commercialization of research results. Powerful impetus to this was given in 1980 in the United States through the adoption of the Bay-Dole Act. In subsequent years, similar laws have been adopted in other countries too, including mechanisms to encourage the development of spinoffs. Secondly, creation of spin-off requires interaction of the four parties: inventor, research organization, entrepreneur, and venture investor. In order to avoid market failures, innovation development requires prior constant interaction among the innovation process participants, i.e., their integration into innovation network. Thirdly, it is possible to quantify the number of companies that are based on the $R \& D$ results, conducted in universities. As the technology which is the subject of commercialization, is created in the university, it must be disclosed in the office of technology transfer, which then will participate in spin-off creation. Of course, a researcher can create a company on his own, but with the help of a database of legal entities this fact can be identified. The same applies to students who have created a company on the basis of their own research results, as W. Hewlett and D. Packard did.

In this study, I will analyze spin-offs, created directly by university. This is due to the lack of databases of graduates (at least in the public domain). Analysis of the founders of the spin-off allows us to characterize companies, related with university through a spin-off: their industry affiliation, size, turnover, regional (country) identity, etc. In scientific literature, spin-offs are not considered from the perspective of affiliation with the business, although the significance of social capital is recognized (Landry et al. 2006). So the purpose of this study is to investigate the following questions: whether universities, as well as Russian regions, considerably vary in intensity of interaction of universities with companies? Are research universities or science-active regions always leaders? Is the integration into personal networks a significant factor of the innovation activity on the regional level?

\section{Literature review}

On the basis of the triple helix concept, it is shown that exchange of information in the triangle universities-industry-government is the basis for the creation of knowledge and its commercialization (Leydesdorff and Fritsch 2005). Of special note is the innovation network as the area of research. In the works of scholars such as Chaminade and Vang (2008), Ferrary and Granovetter (2009), and Saxenian (1995), it was found that one of the main factors of the growth of Silicon Valley were communities, which stimulated networking. Innovation networks can be understood as a mode of organization in which two or more independent firms aim at jointly 
researching, developing or dispersing innovations (Dilk et al. 2008). As such, innovation network is scientific category closely connected with social capital (Wilson 1997; Portes 1998; Woolcock and Narayan 2000; Westlund 2006). For example, Westlund defines social capital as "social, non-formalized networks that are created, maintained and used by the networks' nodes/actors in order to distribute norms, values, preferences and other attributes and characteristics, but which also emerge as a result of actors sharing some of these attributes" (2006 p. 8). Innovation networks can be formal ( $R \& D$ joint ventures, strategic alliances, etc.) or informal, based on personal contacts such as friends, family, previous colleagues, etc. (Pyka 2011). As formal relationships are established and maintained by people, so interpersonal relationships based on trust and mutual respect are the basis of interaction among companies (Kale et al. 2000).

Kosonen (2002) highlights the concept of "institutional capacity," indicating that this includes both communications within the community and with partners from other regions. In other words, the main obstacle to the creation of networks is the absence of network organizers and, as a result, lack of coordination. Etzkowitz (2013) showed that formal technology transfer mechanisms do not always work effectively at early stages of the innovation system development. As a result, they are replaced by interpersonal communication. He cites the example of Brazil, where government encourages the creation of laboratories, which are at the same time small businesses.

It is known that the transfer of knowledge is characterized by geographic concentration and interpersonal contacts as the main channel of communication. This is due to implicitness of knowledge underlying the many innovative ideas (Bathelt et al. 2004). Different types of proximity (institutional, social, cognitive, organizational) influence each other and on the geographic one. Singh (2005) showed that if we take into account the density of interpersonal relationships, the impact of territorial organizational factor decreases. In other words, if the connection between the subjects of the innovation process is quite strong and stable, they do not require the maintenance of territorial or organizational proximity. Geographic factor is significant in establishing the relationship between the agents belonging to different areas (for example, between companies and universities), and less important, if agents come from the same areas, such as universities (institutional proximity compensates for the lack of geographic) (Ponds et al. 2007).

The problem of studying the development of small enterprises (spin-off) created with the participation of universities, and cooperating with them is given the highest priority in the literature. The founder's possession of successful business experience or management experience has positive impact on the size of small innovative enterprises. And matching spheres of activity is not a significant factor (Gottschalk et al. 2009). Experience shows the importance of preliminary integration of the founders of a small enterprise in business networks: a successful business is rarely left by them when registering a new firm. It indirectly indicates that large-sized firms are created with the participation of external firms or former employer.

Differences between small innovative companies and, accordingly, the trajectory of their future growth are largely determined by the characteristics of companies with which they are affiliated. This is due to the fact that the parent company provides material and financial resources and transfers organizational skills and marketing 
knowledge (Klepper and Sleeper 2005). It is noteworthy that such characteristic of technology, which is the subject of commercialization, as variety of applications, has positive effect on the development of academic spin-off. Moreover, if external company is part of spin-off's co-founders team, the dependence becomes reversed. This is explained by the fact that not all possible directions can be mastered with the participation of the parent company; while for reasons of competition, the company may not be interested in the transfer of technology. But the novelty of the technology positively affects only the development of small firms' setup with the participation of external companies (Velde et al. 2008). It means that more successful breakthrough technologies appear on the market only with the assistance of a company that has the necessary additional competencies.

Vinig and Rijsbergen (2009) in their study of innovation universities in developed countries have shown that the choice of such a tool of technology transfer, as the creation of small innovative companies, is determined by development of high school innovation infrastructure (business incubators, technology parks) but not a high level of entrepreneurial culture. The presence of business experience of the head of technology transfer center positively affects only the quantity of innovative ideas reported to center. So it leads only to increase in the degree of confidence on the part of scientists. Disincentives such as low share of scientists in royalties do not have effect on the quantity of spin-off, created with the university participation. In other words, the formation of small enterprises requires real help, not just skills to "pack" project properly. However, the process of creation of small enterprises by scientists is not always carried out with the participation of the university departments. Approximately two thirds of companies established by scientists of Italian universities are not based on patented R\&D results (Fini et al. 2009). In other words, these companies are either based on the know-how created in the university (and this is a reason for lawsuit) or business is not directly related to the commercialization of innovation. Companies created by university graduates are even greater in "blank" size. According to research of graduates employment, on average, a quarter of graduates of MIT, the business school at Stanford University, and Tsinghua University sets up a company; at the University of Chalmers (Sweden), this proportion reaches $42 \%$. As a result, for years 1980 to 2003, the ratio of small firms created by graduates and employees of the university at MIT is 48:1 (Astebro et al. 2010). In universities, where small businesses are created intensively, the practice of inviting entrepreneurs to manage these companies is widely distributed. Often former graduates act as entrepreneurs.

Finally, regression analysis, conducted on the basis of small innovative enterprises in Italy, showed that link with another company has positive and significant effect on growth of the number of employees in a small business but not the size of the assets or revenues (Balderi and Piccaluga 2010). This fact may indicate that spin-off principally plays a role of the company-developer of innovation, which will then be integrated into the portfolio of a large company.

Thus, the assessment of the potential development of academic spin-off requires analysis of stable resource flows sources. Concerning the economy with underdeveloped technology sector and weak innovation infrastructure only external companies could be that source. 


\section{Methodology}

If you talk in terms of the linear concept of the innovation process, the spin-off should be established to develop independently or later be sold to bigger companies. But there are two aspects. First, in Russia licensing of intellectual property is economically disadvantageous for the university. According to the norms of fiscal legislation, entire income from licensing must be transferred to the federal budget. Transaction costs to protect the rights of the licensor are high. Development of license agreements requires highly skilled specialists which could be employed only in a few major cities. Secondly, according to official statistics, universities account for only $6.7 \%$ of the total business expenditures on R\&D (Science Indicators 2010). Large companies prefer to apply to scientific organizations, including ones that are controlled by them. Small and medium-sized companies use informal relations with individual employees of universities (former lecturers, colleagues, classmates, friends, etc.) to carry out research. Often, employees are co-founders of these companies. Thus, the creation of spin-off for the university is practically the only way to commercialize intellectual property and get income. But as efficiency of innovation infrastructure is low, interaction with external firm is virtually the only way to obtain the resources necessary for start-up development: financial, marketing, production, etc. In this case, the interaction of universities with external companies is necessary: the amount of personal funds of university staff is rarely sufficient for the commercialization of ideas. Intensity of such cooperation should be higher in more innovation-active regions. On the one hand, the innovation network allows intensifying the innovation process in the region, as it facilitates interaction between representatives of different fields (science and business). On the other hand, in a more innovation-active region, the demand for research services and innovative products is higher.

Inter-firm linkages can be formal or informal. Informal contacts could be implemented between, say, relatives, former colleagues, etc. They could be difficult in detectability, for example, because of trade secrets, so I will focus on the analysis of relations with the formal features. At first, it may be tied between subsidiaries and affiliated entities. Say, firm-co-founder of small innovative enterprise may belong to a larger structure, which in turn is affiliated with the research institute, financial companies, etc., i.e., integrated into the innovation network. However, property in Russia is often personified. In other words, the connection between formally independent firms is made possible through the same individual co-founders. Accordingly, the algorithm of the study is as follows:

1. As an information base for the analysis of the small innovative companies, I used information-analytical database FIRA-PRO. I collected the following information for spin-offs from 61 regions: industry affiliation of external investors, their turnover (if present), the presence among the CEO (founders) of small enterprises of real work experience in business until 2009, and personal affiliation of spin-off owners with other companies. In total, I have studied almost 2000 academic spin-off established until May 2014.

2. Next, for each small innovative enterprise and its affiliated structures, it was carried out search for information on the Internet in order to get a better idea about the scope and scale of the activities of external companies. 
3. Since the quantification of the intensity of contacts is characterized by methodological difficulties (the number of contacts does not always turn into quality), I used the scores, based on available information:

0 point-no ties

1 point-connection exists; however, financial information is not provided or the total annual turnover of affiliated companies is less than ten million RUB. In the case when the financial data are not presented, I checked, if someone of a spin-off's co-founders has status of the private entrepreneur. As a rule (in $97 \%$ of cases), this status was missing. This fact could be considered as an indirect proof that primarily financial statements are not presented by the enterprises with the lack of turnover. But since they can engage in activities informally and have some resources to commercialize innovative project, I assumed to these companies 1 point.

2 points - the total annual turnover is more than ten million RUB, but the spin-off's founders play a subordinate role in this external company (or they are just affiliated with founders of large companies on other projects).

3 points-if the founders of small innovative enterprises at the same time play a dominant role in the management of companies with a total turnover more than ten million RUB.

What is better: to be acquainted with entrepreneur who possessed company with one million USD turnover or control a company with just say 0.1 million USD turnover? This question does not have clear answer. It requires analysis of efficiency of spin-off with different types of innovation network connection. It is impossible because of some reasons (financial data are not presented for a lot of spin-offs; spin-offs belong to different industries, regions; innovative ideas are at different stages of readiness, etc.). Concerning financial constraints of Russian university innovators, I made a proposition that control over some resources is much more reliable than just possibility to get these resources. So if co-founders of spin-off control a company with turnover more than ten million RUB this spin-off gets 3 points evaluation.

Of course, the amount of accumulated wealth of the co-founder would be the most reliable indicator of his investment opportunities. However, obtaining this information is not possible for objective reasons. The same applies to the profit of companies, affiliated with co-founder of the spin-off. Because of the possibility of tax manipulation with costs (and hence profit), it is difficult to determine the actual size of the profit, especially accumulated one. Therefore, as an indicator of co-founder investment opportunities, I chose cumulative revenue of companies with which he is affiliated. But ad hoc, I considered significant affiliation with the company, whose turnover slightly less than ten million RUB, but high and stable for several years. I was motivated by the fact that the accumulated profit may well be sufficient to implement innovative project of spin-off.

The average value of the investment required for the project in the field of information technology in Russia is 32 million RUB, biotechnology-58.6 (Estimation of investment index of start-up creation and basic characteristics of start-ups 2011). Of course, the project in the creation of software is less capital-intensive than, say, mechanical engineering. However, I conducted an analysis of articles in the journal "Expert," devoted to the practice of start-up creation in Russia. It could be concluded 
that there is considerable variation. The required size of the investment depends on the objectives of the investor, the implementation phase of the project, the level of support from state organizations (subsidies, participation in government programs of basic and applied research, place in a business incubator or technology park, tenancy in university, access to the results of university research, researchers, laboratory equipment, etc.), and industry affiliation of the project. Some projects in the field of education, 3D-printing, and mobile applications require an order of magnitude lower cost. Also it could be confirmed by sociological research on spin-off development (Grasmik and Terentyeva 2011; Grasmik 2014). This is largely due to the fact that the company is engaged in de facto adaptation of outside innovation to the local market needs. The ten-million-RUB threshold level of revenue cannot be rigorously justified. Since the level of profitability of Russian companies in the real sector is about 10-20\%, the profits and assets of the firm with a turnover may well be a source of 3-4 million RUB of capital per year. Besides, there are the following reasons:

1. Innovative projects even in Russian universities vary considerably in the degree of R\&D intensity, radicalism of innovation, payback period, and hence on the value of the initial investment required.

2. Spin-offs may use the material resources of affiliated organizations: the premises, equipment, management services-not just financial. Therefore, even low-profit organizations can contribute to the development of innovative project of a small business.

It is worth adding that the financial information is not presented for all companies. Financial statements may be undervalued due to informal activity (especially in the sphere of trade and services).

For the analysis, I took companies that were created by Russian universities after the August 2009. Totally, 2653 firms were created. But because firm could be created by university not only for commercializing of innovation but just for practical purposes, only firms whose products could potentially be high-tech were selected for the study. In other words, companies whose priority activities is trade, lease, advisory services, publishing, etc., and also spin-offs, which in fact perform function of Office of Technology Transfer, were excluded from consideration.

In addition to the industry classification codes, I have used the database of the spin-offs compiled by the Center of Science Research and Statistics (CSRS). Firms that do not meet the formal features of the spin-off under the Russian law (for example, the share of university in the authorized capital) are not included in CSRS database. Moreover, it is formed with a delay. But if the firm is included in the CSRS database, I collected additional information about it from public sources, primarily from the site of the university, on the basis of which I took the decision to include it in the sample or not. I excluded companies which were created solely by the university or were liquidated to date.

I took into account the fact that the same entrepreneur may be a co-founder of several spin-offs. To avoid double counting, I set points for connection to only one company. If the spin-off was created by several universities, the scores were divided equally between them. 


\section{Spin-off: regional differences}

In 2009, Russian universities and research institutes have received the right to contribute intellectual property in the authorized capital of the company without the consent of the founder (usually Ministry of Education) and, consequently, to create spin-offs as a result of the adoption of the Federal Law No. 217-FZ of 02.08.2009. However, informal cooperation between scientists of universities (research organizations) and companies, often carried out with the support of the university administration, and before passing the law was pretty intense. The low level of wages in technical universities, the need to keep staff, resource constraints, and stringent business environment contributed to a mutual interest in cooperation. In spite of the fact that spin-offs received a number of benefits (tax breaks, the ability to get space for rent from the university without competition, benefits to pay social security contributions), some experts believe that the vast majority of spin-offs are not viable, created exclusively for grants and conducting transactions for the purchase of low-cost equipment.

Many of the institutional problems of creating spin-offs were resolved to date. So economic obstacles became the main ones. For example, many universities at the time of the adoption of the Federal Law No. 217-FZ did not have intellectual property on the balance sheet: transfer of income from the sale of licenses to the federal budget and the need to pay for the maintenance of patents and income tax were the reasons. Therefore, in many cases, staff of universities registered intellectual property rights themselves. As a result, many universities do not have effective services for commercialization of research results.

Since the beginning of the 217-FZ law to 15 May, 2014, 2653 companies were founded by Russian universities. However, after the amendments (liquidated companies, university business units, non-technological firms, etc.), the actual number of spin-off is equal to 2074. According to the CSRS, at the beginning of July 2014, the quantity of spin-off, complying with the 217-FZ, was 1863 , but universities have created 1792, and the rest-research organizations (ten-jointly).

Of the total number of examined firms, almost half has no ties with external companies ( 0 point), in a quarter of cases this interaction takes place either with small firms or with companies whose turnover I failed to learn (1 point). Finally, in the remaining cases (about equally), it was well established that the co-founders of small innovative enterprises are affiliated with co-founders (directors) of other companies with larger businesses ( 2 points) or they themselves are experienced entrepreneurs (3 points) (see Table 1).

As an example of two-point-type interaction, I can lead "Potential" Ltd. (Bashkir State University), whose co-founder is NPF "GEOTEK"-a subsidiary of the largest mining exploration company in Russia-"Bashneftegeofizika" (turnover including subsidiaries exceeds 6.2 billion RUB). Along with this, the co-founders of the company are individuals-almost all are employees of the Department of Geophysics of the Bashkir State University; director of the company is at the same time the Department Head. An example of three-point-type interaction is the largest IT company in Perm-IVS, which created several small enterprises in Perm universities.

The number of new spin-off is characterized by seasonality (the first and last quarters of the year are characterized by greater activity) and has been steadily declining (see Fig. 1 for an illustration). Dynamics of companies with connections to the business at 
Table 1 Distribution of spin-off

\begin{tabular}{lccccc}
\hline & No ties & 1 point & 2 points & 3 points & Total \\
\hline Quantity of spin-off & 972 & 520 & 255 & 327 & 2074 \\
Share (\%) & 46.9 & 25.1 & 12.3 & 15.7 & 100 \\
\hline
\end{tabular}

the levels 2 and 3 points in general follows trends in the total number of spin-offs, but the proportion of such firms reduces. In 2010, the share of such firms was $34 \%$, in 2013 - only $26 \%$. It means that there is impending exhaustion of accumulated baggage of innovative ideas and persons able to implement them in practice.

Russian regions differ significantly in the number of established academic spin-off. So, in Tomsk region, 97 companies were created; in Tatarstan-98; in SaintPetersburg-137; and in Belgorod region-80 firms. At the same time in such major areas as Novosibirsk region, Samara region, and Bashkortostan universities created, respectively, 44, 51, and 33 companies. In such a large region as Irkutsk region to date, there are only 25 companies.

There are significant differences among regions in the number of spin-offs with two and three grades business-level contacts. Thus, leading territories in 2-point contact level, i.e., affiliation with the external entrepreneurs, are Moscow, Tatarstan, SaintPetersburg, Tomsk, and Nizhny Novgorod regions. In the latter region, every third spin-off is characterized by the presence of such links. Eight small innovative firms were established in Belgorod and Chelyabinsk regions in each one. In this case, the contacts with the business venture are close to the standard, the inventor receives some share in the project in exchange for his active participation. The highest quantity of spin-off, in which the entrepreneurs are directly co-founders, is in Moscow-54, in Saint-Petersburg-34, and in Tomsk and in Rostov-18. In addition, in Perm and in Omsk, there are 11 such firms in each one.

Calculation of the cumulative index characterizing the intensity of contacts as a sum of multiplications of points to the number of the firms indicates that Moscow and Saint-Petersburg leads with large advantage from others-277 and 195. Tomsk which got the next place has 110 grades and Tatarstan-87. Novosibirsk region, with its considerable scientific potential, has only 43 (see Table 2).

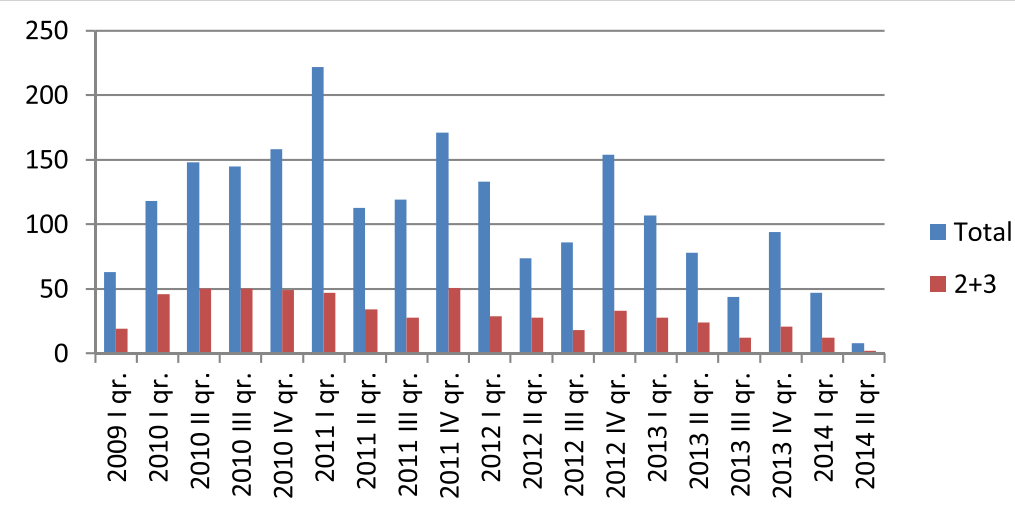

Fig. 1 Dynamics of creating spin-offs in Russia 
Table $\mathbf{2}$ Characteristics of spin-off innovation networks in some regions

\begin{tabular}{lcccc}
\hline Region & 1 point & 2 points & 3 points & Cumulative index \\
\hline Moscow & 44 & 31 & 57 & 277 \\
Saint-Petersburg & 37 & 28 & 34 & 195 \\
Tomsk & 26 & 15 & 18 & 110 \\
Tatarstan & 30 & 18 & 7 & 87 \\
Rostov & 9 & 5 & 18 & 73 \\
Omsk & 14 & 5 & 11 & 57 \\
Belgorod & 20 & 8 & 8 & 60 \\
Novosibirsk & 11 & 6 & 8 & 47 \\
\hline
\end{tabular}

The last case is the apparent paradox that needs further investigation. One possible explanation is the dominance of informal interaction between scientists and entrepreneurs, bypassing college, in the Novosibirsk region. It is especially the case in laborintensive industries, such as IT.

\section{University differences}

All spin-offs, representing a sample, were created by 303 universities. The distribution of universities in the number of spin-off shows, on the one hand, the presence of a group of leaders, which have created more than 30 companies each. On the other hand, the creation of spin-off actively takes place in many universities. More than ten companies were created in 50 universities in Russia (Table 3).

However, the number of spin-off does not say anything about their viability. In many ways, it is determined by university policy: either to create as many firms as possible (to improve the formal parameters, in the hope that some spin-offs will be successful) or strictly viable ones. So, at Moscow State University named after M.V. Lomonosov, one of the leading universities in Russia, just nine companies were created till now. However, six spin-offs have connections with business at 3-point level and three at 2-point level. Of the seven spin-off of the Russian University of Oil and Gas named after I.V. Gubkin, connection with the business in five companies is estimated at 3 points. On the contrary, in Belgorod Technical University named after V.G. Shukhov, 55 companies were created, but only four (!) are known to be viable (due to business connections at 2 or 3 points). For comparison, in Belgorod National Research University, there are eleven such firms. In my opinion, these significant differences between the universities cannot be fully explained by random fluctuations or the size of the region's economies. University policy to encourage entrepreneurship and term of its duration, availability of innovation infrastructure and the technical level of available laboratory equipment are more relevant factors. Consequently, the number of viable spin-off, as the outcome measure, can be used to evaluate the effectiveness of the selection of universities under government programs to stimulate

Table 3 Distribution of Russian universities on spin-off quantity

\begin{tabular}{lcccccccc}
\hline & \multicolumn{1}{l}{ Category } & & & & Total \\
\cline { 2 - 9 } & $51-60$ & $41-50$ & $31-40$ & $21-30$ & $11-20$ & $1-10$ & \\
\hline Number of universities & 2 & 0 & 7 & 14 & 39 & 241 & 303 \\
\hline
\end{tabular}


innovation. At the present stage of economic development, university must be entrepreneurial, i.e., direct efforts not only on conducting R\&D but also on the creation of a system of institutions to commercialize the results.

Thus, in 2009 and 2010, contests were held on the status of a research university in Russia for a period of 10 years. As a result, the status of a research university was awarded to 29 organizations. This status implies payment of subsidies, on the one hand, and achievement of target indicators, on the other. Among the indicators, there is ratio of sales of scientific and technical products to the federal budget expenditures on research conducted at the university. In fact, this is an analog of profitability costs. Also at this time, federal universities were established by merging several universities with additional financing for 3 years. In general, the selected leaders confirm this status: only two out of the fifteen leading universities do not have any status (see Table 4).

Of course, some universities with special status are close to the leading group. So they cannot be clearly assigned to outsiders. However, a number of universities rounded out the top 100. These include major metropolitan universities. Perhaps this is due to the orientation of their research to the needs of large enterprises, capital-intensiveness of innovation projects they developed (for example, in energy sector).

On the one hand, it may seem that there is a direct correlation between the location of the university in the ranking and its size. Indeed, almost all leading universities are well-known educational institutions of Russia with positive reputation. However, I would like to note that almost all of the top ten universities, for example, created more spin-off with the assessment of 3 points than spin-off with the assessment of 2

Table 4 Leading universities in spin-off creation

\begin{tabular}{|c|c|c|c|c|c|}
\hline University & 2-point spin-off & 3-point spin-off & $2+3$-point spin-off & Cumulative index & Status \\
\hline NRTPU & 5 & 7 & 12 & 41,5 & Research \\
\hline SPbNRUITMO & 5 & 7 & 12 & 40 & Research \\
\hline UFU & 9 & 3 & 12 & 38 & Federal \\
\hline SUSU & 4 & 7 & 11 & 38 & Research \\
\hline SRSPU & 3 & 10 & 13 & 38 & None \\
\hline TUSUR & 4 & 7 & 11 & 37 & None \\
\hline NRBSU & 4 & 7 & 11 & 36 & Research \\
\hline NRMSTU & 1 & 10 & 11 & 35 & Research \\
\hline NRTSU & 3 & 6 & 9 & 31 & Research \\
\hline KNRTU & 5 & 3 & 8 & 29 & Research \\
\hline PNRSTU & 2 & 7 & 9 & 27 & Research \\
\hline SSU & 3 & 6 & 9 & 27 & Research \\
\hline SPbSPU & 1 & 7 & 8 & 27 & Research \\
\hline MSU & 3 & 6 & 9 & 24 & Special status \\
\hline KNRTU-KAI & 3 & 3 & 6 & 23 & Research \\
\hline VorSU & 4 & 3 & 7 & 23 & None \\
\hline USMU & 1 & 5 & 6 & 23 & None \\
\hline SPbSETU & 5 & 3 & 8 & 23 & None \\
\hline BSTU & 3 & 1 & 4 & 22 & None \\
\hline KFU & 6 & 1 & 7 & 21 & Federal \\
\hline
\end{tabular}

Two universities in Russia: MSU and SPbSU are considered as national domain, so they possess special privileges 
points. And the next ten universities made just the opposite. So in leading universities, connection with the business is more pronounced. Experienced entrepreneurs are directly involved in the commercialization of innovations. The quantity of spin-off does not play a meaningful role: some of the top 100 universities have created as many companies as the leading ones.

\section{Spin-off and regional innovation activity}

Many factors determine the decision to create spin-off. At first, these could be meso- and macro level factors. For example, it may be the dynamics of the high-tech industries, the size of the local market, the level of interest rates, the availability of staff with appropriate skills, etc. However, in general, researchers consider micro level parameters. First of all, the impact of the financial parameters is considered, such as the size of necessary funding and its possible sources, taking into account the stage of development of the company. According to some scholars, the more risky the project is, the more likely the owner will try to attract venture capital funding (Carpenter and Petersen 2002). The level of publication activity of the university scientists does not affect their desire to create a company. The researcher may continue to publish, acting as a scientific consultant of the company. The presence of intellectual property rights, the practical orientation of research, and university or laboratory size are much more important factors (Landry et al. 2006). Direct relationship with the size of the university is due to the possibility of interdisciplinary research, attracting leading scientists, economies of scale in creating laboratories, and facilities of innovation infrastructure.

Innovation network is treated as a separate factor and is a component of other parameters at the same time (Landry et al. 2006; Grandi and Grimaldi 2003; Lin et al. 2006). For example, the involvement of venture investor, participation in joint research projects with companies, the availability of business experience, participation in international research projects, and market-oriented style of management (Abbate and Cesaroni 2014) bring not only knowledge or financial resources but also create the necessary social contacts. Integration into innovation network usually has significant and positive effect on probability of spin-off creating (Krabel and Mueller 2009; Landry et al. 2006; Landry et al. 2007), professional staff recruitment and research collaboration (Keeble et al. 1999), and firm innovation activity as a whole (Silva and Leitao 2007). Hence, larger number of spin-offs, having a strong association with outside companies, ceteris paribus, reflects the greater density and efficiency of local innovation networks. Therefore, the following provision must be true: the greater the number of viable spin-off in the region, the higher the level of innovative activity of local companies. To test this hypothesis, I used correlation analysis (Spearman correlation coefficient). From the analysis, I excluded regions in which the higher education and science sector are virtually absent, as it is obvious that in these regions spin-offs could not exist. First of all, there are some regions of North Caucasus, Far East, and Siberia. In order to smooth out annual fluctuations, I calculated the indicators of innovation activity in the region as the average for 2010-2012. See results in Table 5.

Correlation analysis between the indicators of the intensity of contacts with business and indicators of the innovative activity in the regions of Russia (the share of industrial enterprises engaged in technological, organizational and marketing innovation, the share 
Table 5 Correlation analysis of spin-off and regional innovation activity

\begin{tabular}{|c|c|c|c|}
\hline & Share of innovation-active enterprises in region & Innovative product to total product ratio & Expenditures on innovation to total product ratio \\
\hline Cumulative Index & $0.413^{b}$ & $0.279^{a}$ & $0.434^{b}$ \\
\hline $2+3$-point spin-off & $0.412^{b}$ & $0.353^{b}$ & $0.428^{b}$ \\
\hline Quantity of spin-off & $0.422^{b}$ & $0.233^{\mathrm{a}}$ & $0.407^{b}$ \\
\hline
\end{tabular}

avariable significant at $5 \%$

bariable significant at $1 \%$ 
of innovative products in shipped products industry, the ratio of innovation costs to the volume of products shipped) showed the presence of a positive relationship with the resulting performance, especially with share of innovation-active organizations and expenditures on innovation to total product ratio. This is understandable: the higher the level of innovation activity in the economy of the region as a whole, and not only in large companies, the higher the motivation to cooperate with local universities.

Moscow and St. Petersburg considerably outperform other cities in size and economic parameters, while concentrating considerable scientific potential. As a result, they considerably stand out from the sample. To eliminate possible distortions, I repeated the calculations without these two observations. All results remain significant.

The presence of a positive relationship between innovation activity in the region and the spin-off indicators may be due to the size of the region. Indeed, in a larger area, there are more opportunities for cooperation, a large market, and infrastructure more prepared for production activities. Also corruption is less due to the higher level of competition and regional power is less authoritarian, too. It is easier to find (or draw) the staff with necessary skills and so on (Grasmik 2011). To test this hypothesis, I calculated the same indicators of spin-offs but per 1000 university teachers operating in the region and performed a similar correlation analysis. The results did not change substantially. The closest connection is with the observed share of innovation-active enterprises (I also made calculations without Moscow and St. Petersburg). In other words, in the region with a higher level of innovation activity of companies businessuniversity interaction is more intensive, too.

It is noteworthy that higher values of the relative spin-off indicators are observed in small regions (Belgorod, Kurgan, Omsk, Tambov). Concerning viable spin-off $(2+3$ points) the greatest index is in Tomsk region-6.21. In Belgorod, it is equal only 4.95, in the major industrial centers, it lies in interval of $2-3$. The dependence between the number of university teachers and the ratio of the number of spin-offs $(2+3$ points) per 1000 teachers is positive and significant. Therefore, the effects of region size described above could be quite relevant.

I pointed out before that, depending on the type of interaction with external companies, spin-off got 1-, 2-, or 3-point estimation. Reflecting the differences in resource opportunities, this gradation does not reflect differences in the probability of successful commercialization of innovations in the case where the developer has experience in entrepreneurship, affiliated with a successful entrepreneur, and when he is entrepreneur himself. Therefore, all the calculations of the cumulative index were repeated in case of higher gap between the estimates: $1,2,4 \ldots 1,2,7 ; 1,3,4 \ldots$ $1,3,7 ; 1,4,5 \ldots 1,4,8$. The values of the coefficients with increasing scores did not change fundamentally. In some cases, their significance is increased.

\section{Conclusions}

It is known that innovation network has impact on innovation system functioning and its effectiveness. But there is problem of designing an appropriate indicator, which would be relevant and comparable to all regions and reflect network collaborations. I think that spin-off collaboration with other companies could serve as indicator of regional innovation network collaboration. 
Firstly, the creation of high-tech start-up requires the cooperation of all stakeholders: inventor, entrepreneur, investor, and university as an organization whose resources are used in the development of innovative ideas. As it is known, the innovation process is nonlinear, i.e., interaction of the participants of the innovation process does not necessarily end up with the achievement of some intermediate result. Modern hightech firms to remain competitive need university as a permanent partner and vice versa. Secondly, licensing of scientific results is not always the best way of technology transfer. In the absence of adequate guarantees of property rights, high transaction costs of their protection and reinstatement, the high cost of patenting in several countries, and finally, the need to supplement the explicit knowledge with implicit one, it is necessary to maintain constant contact between the entrepreneur and inventor to develop a mechanism of mutual guarantees of interest.

Using of the information about the founders of firms is a reasonable alternative to the social networks (like Facebook and LinkEdIn) as a source of information about contacts. Thanks to the taxpayer identification number, it is possible to reliably trace the connection between person and the company. In addition, not all people especially belonging to older generation are represented in social networks. The proposed methodology does not have absolute rigor, but it is due solely to the inability to unambiguously quantify all the numerous aspects of the cooperative interaction of companies with each other and with universities. The size of the turnover of affiliated companies is not the only indicator showing the potential benefits of cooperation. Much depends on the closeness of the connection of spin-off's co-founders and external firms. For example, the co-founder of an external company may be a relative of one of the owners of the spinoff. Of course, this factor will provide the closest interaction, leveling the smaller size of the available resources. Among other shortcomings of methodology, I would like to note the absence of a clear quantitative distinction between different categories of links to external companies: inability to detect the entire range of relations (e.g., if cofounders' relatives, affiliated with big companies, have other last names).

The use of different scores or adjustment of the composition of observed objects did not change the results. This allows me to conclude that the proposed methodology is relevant. However, elaboration of spin-off's accessory to a particular category (with the appearance of reporting data in the database FIRA-PRO or information in the public domain) would adjust the value of the variable characterizing the density of social ties in the region. Sociological research would allow to clarify the nature of occurrence of contacts between the owners of firms, as well as to show the impact of integration in the innovation network on individual components of the spin-off development.

The results obtained in this study can be productively used to analyze some more applicable issues. For example, in a number of cases, the presence of co-financing partner is directly claimed by the conditions of contests for state subsidies to support research and innovation projects. However, during the business plan competition, it is possible to prepare documentation (develop plan of promotion, production, assessment of market size, provision, obtain reviews of potential customers, etc.) only in the presence of partners or business experience (i.e., once established contacts).

Another direction of using results is compounding of ranking of regional innovation activity. Typically, these ratings are based on performance-related research activities and economic potential. Innovation network variable is not considered, since the creation of 
relevant indicators that can be used for inter-regional comparisons, is a nontrivial task. Instead researchers use different ratings of the institutional environment. In my opinion, the use of the indicator directly related to the commercialization of innovation is more productive.

\section{Additional file}

Additional file 1: Translation of the abstract into Arabic.

Competing interests

The author declares that he/she has no competing interests.

\section{Acknowledgements}

The author gratefully acknowledges two anonymous referees for their valuable comments. All remaining errors are the author's alone. Author acknowledges the financial support of the Russian Fund of Fundamental Research under grant no. 13-06-98042 "Creating of effective regional innovation systems in Russia: analysis of role of innovation networks."

Received: 24 November 2014 Accepted: 8 June 2015

Published online: 07 July 2015

References

Abbate T, Cesaroni F (2014) Market orientation and academic spin-off firms. Working Paper Business Economic Series. Universidad Carlos III De Madrid, WP. 14-01

Astebro T, Bazzazian N, Braguinsky S (2010) Startups by recent university graduates and their faculty: implications for university entrepreneurship policy. http://papers.ssrn.com/sol3/papers.cfm?abstract_id=1752832. Accessed 15 September 2014

Balderi C, Piccaluga A (2010) A theoretical and empirical contribution for a better understanding of academic spin-offs' growth patterns. http://ideas.repec.org/p/sse/wpaper/201004.html. Accessed 15 September 2014

Balland PA (2012) Proximity and the evolution of collaboration networks: evidence from research and development projects within the global navigation satellite system (GNSS) industry. Reg Stud 46:741-756

Bathelt H, Malmberg A, Maskell P (2004) Clusters and knowledge: local buzz, global pipelines and the process of knowledge creation. Prog Hum Geogr 28(1):31-56

Boschma RA (2005) Proximity and innovation: a critical assessment. Reg Stud 39:61-74

Boschma RA, Broekel T (2012) Knowledge networks in the Dutch aviation industry: the proximity paradox. J Econ Geogr 12(2):409-433

Carpenter RE, Petersen BC (2002) Capital market imperfections, high-tech investment and new equity financing. Econ J 112(477):34-72

Cassi L, Plunket A (2013) Proximity, network formation and inventive performance: in search of the proximity paradox. http://mpra.ub.uni-muenchen.de/47388/1/MPRA_paper_47388.pdf. Accessed 15 September 2014

Chaminade C, Vang J (2008) Globalization of knowledge production and regional innovation policy: supporting specialized hubs in the Bangalore software industry. CIRCLE Electronic Working Papers. No. 2008/20. Centre for Innovation, Research and Competence in the Learning Economy (CIRCLE) Lunds Universitet

Degroof JJ, Roberts EB (2003) Spinning-off new ventures from academic institutions in areas with weak entrepreneurial infrastructure: insights on the impact of spin-off processes on the growth-orientation of ventures. http://dspace.mit.edu/ bitstream/handle/1721.1/3524/4311-03.pdf?sequence=2. Accessed 15 September 2014

Dilk C, Gleigh R, Wald A (2008) State and development of innovation network. Manag Decis 46(5):691-701

Erden Y, Yurtseven AE (2012) Establishment and development of academic spin-off firms by evidence from Turkey and some policy recommendations. http://stps.metu.edu.tr/sites/stps.metu.edu.tr/files/1204.pdf. Accessed 10 August 2014

Estimation of investment index of start-up creation and basic characteristics of start-ups (2011) Rating agency Expert-RA. http://www.rusventure.ru/ru/programm/analytics/docs/Index_startup.pdf. Accessed 27 May 2014

Etzkowitz H (2013) Silicon Valley at risk? Sustainability of a global innovation icon: an introduction to the special issue. Soc Sci Inf 52(4):515-538

Ferrary M, Granovetter M (2009) The role of venture capital firms in Silicon Valley's complex innovation network. Econ Soc 38(2):326-359

Fini R, Grimaldi R, Sobrero M (2009) Factors fostering academics to start up new ventures: an assessment of Italian founders' incentives. J Technol Transfer 34:380-402

Gottschalk S, Miller K, Niefert M (2009) Founder's human capital, entry strategies and start-up size. ZEW Discussion Papers 09-030. Center for European Economic Research

Grandi A, Grimaldi R (2003) Exploring the networking characteristics of new venture founding teams. Small Bus Econ 21:329-341

Grasmik K (2011) Regional management as a factor of innovation in Russian regions: statistical analysis. http://papers.ssrn.com/ sol3/results.cfm. Accessed 16 August 2014

Grasmik K (2014) Cooperation among university scientists and entrepreneurs as a factor of small innovative enterprises development. Innovations 1:40-47

Grasmik K, Terentyeva O (2011) Innovation activity of high-tech enterprises in Russia. ECO 8:16-34

Kale P, Sinch H, Perlmutter H (2000) Learning and protection assets in strategic alliances: relational capital. Strateg Manag J 21:217-237 
Keeble D, Lawson C, Moore B, Wilkinson F (1999) Collective learning processes, networking and 'institutional thickness' in the Cambridge region. Reg Stud 33(4):319-332

Klepper S, Sleeper S (2005) Entry by spinoffs. Manag Sci 51(8):1291-1306

Kosonen KJ (2002) Building innovation capability in the less favored regions-university collaboration as a tool. http:// www-sre.wu-wien.ac.at/ersa/ersaconfs/ersa02/cd-rom/papers/311.pdf. Accessed 02 July 2014

Krabel S, Mueller P (2009) What drives scientists to start their own company?: an empirical investigation of Max Planck society scientists. Res Policy 38(6):947-956

Landry R, Amara N, Rherrad I (2006) Why are some university researchers more likely to create spin-offs than others? Evidence from Canadian universities. Res Policy 35(10):1599-1615

Landry R, Amara N, Saihi M (2007) Patenting and spin-off creation by Canadian researchers in engineering and life sciences. J Technol Transfer 32(3):217-249

Leydesdorff L, Fritsch M (2005) Measuring the knowledge base of regional innovation systems in Germany in terms of a triple helix dynamics. http://econstor.eu/bitstream/10419/22509/1/fritsch_10_2005.pdf. Accessed 15 September 2014

Lin BW, Li PC, Chen JS (2006) Social capital, capabilities and entrepreneurial strategies: a study of Taiwanese high-tech new ventures. Technol Forecast Soc Change 73:168-181

Ponds R, van Oort FG, Frenken K (2007) The geographical and institutional proximity of research collaboration. Pap Reg Sci 86:423-443

Portes A (1998) Social capital: its origins and applications in modern sociology. Annu Rev Sociol 24:1-24

Pyka A (2011) Avoiding evolutionary inefficiencies in innovation networks. http://opus.uni-hohenheim.de/volltexte/ 2011/654/pdf/fzid_dp_2011_35_Pyka.pdf. Accessed 15 September 2014

Ramachandran K, Ramnarayan S (1993) Entrepreneurial orientation and networking: some Indian evidence. J Bus Ventur 8:513-524

Saxenian A (1995) Creating a twentieth century technical community: Frederick Terman's Silicon Valley. http:// people.ischool.berkeley.edu/ anno/Papers/. Accessed 15 September 2014

Science Indicators (2010) Statistical yearbook. Higher School of Economics, State University

Silva MJ, Leitao J (2007) Cooperation in innovation practices among Portuguese firms: do universities interface innovative advances? http://mpra.ub.uni-muenchen.de/5215/1/MPRA_paper_5215.pdf. Accessed 15 September 2014

Singh J (2005) Collaborative networks as determinants of knowledge diffusion patterns. Manag Sci 5:756-770

Velde E, Bart C, Wright M (2008) The technology endowments of spinoff companies. http://www.FEB.UGent.be/nl/ Ondz/wp/Papers/wp_08_513.pdf. Accessed 15 September 2014

Vinig T, Rijsbergen P (2009) Determinants of University Technology Transfer-comparative study of US, Europe and Australian universities. http://papers.ssrn.com/sol3/papers.cfm?abstract_id=1324601. Accessed 15 September 2014 Westlund H (2006) Social capital in the knowledge economy: theory and empirics. Springer, Berlin

Wilson PA (1997) Building social capital: a learning agenda for the twenty-first century. Urban Stud 34:745-760

Woolcock M, Narayan D (2000) Social capital: implications for development theory, research and policy. World Bank Res Observ 15:225-249

\section{Submit your manuscript to a SpringerOpen ${ }^{\circ}$ journal and benefit from:}

- Convenient online submission

Rigorous peer review

- Immediate publication on acceptance

- Open access: articles freely available online

- High visibility within the field

Retaining the copyright to your article 